\title{
Corrigendum
}

\section{Integrating livestock, agriculture and forestry at the landscape scale. Experiences in West Africa and Brazilian Amazon Regions - CORRIGENDUM}

Poccard-Chapuis René, Ba Alassane, Navegantes Livia, Thales Marcelo, Claudino Livio, Ferreira Laura and Coulibaly Doubangolo

doi:10.1017/S2040470010001354; published by Cambridge University Press, 8 November 2010

In the abstract by Poccard-Chapuis René, Ba Alassane, Navegantes Livia, Thales Marcelo, Claudino Livio, Ferreira Laura and Coulibaly Doubangolo presented in Advances in Animal Biosciences, the author names were listed incorrectly. The correct authorship is:

René Poccard-Chapuis, Alassane Ba, Livia Navegantes, Marcelo Thales, Livio Claudino, Laura Ferreira and Doubangolo Coulibaly The editors apologise to the authors and readers for this mistake.

\section{Reference}

René P-C, Alassane B, Livia N, Marcelo T, Livio C, Laura F and Doubangolo C 2010. Integrating livestock, agriculture and forestry at the landscape scale. Experiences in West Africa and Brazilian Amazon Regions. Advances in Animal Biosciences 1, 521. 